\title{
River flood inundation mapping in the Bago River Basin, Myanmar
}

\author{
Win Win Zin ${ }^{1}$, Akiyuki Kawasaki ${ }^{2}$ and Shelly Win ${ }^{1}$ \\ ${ }^{1}$ Department of Civil Engineering, Yangon Technological University, Myanmar \\ ${ }^{2}$ Department of Civil Engineering, The University of Tokyo, Japan
}

\begin{abstract}
:
Flood inundation maps were generated in the Bago River Basin, Myanmar. Although the design of our study was not new, it is one of very few to have analyzed a flood inundation area in Myanmar. Nine flood events were applied to calibrate and validate the results. The flood-inundated area was validated with satellite image for the year 2006. The flood inundation maps with different return periods were delineated. Considering the 50- and 100-year return period flood scenario, the highest depth of inundation may affect the urban area of Bago. The information derived from this study can contribute to assessments of potential flood damage for the local region and for other locations where data is limited.
\end{abstract}

KEYWORDS flood inundation maps; Bago River Basin

\section{INTRODUCTION}

Although floods occur most years in monsoon-affected countries, many countries still lack flood hazard maps to prevent or mitigate the damage. This is particularly true of flood prone countries such as Myanmar. Various studies were conducted on the effects of Cyclone Nargis in 2008 (ADPC and DMH, 2008; Fritz et al., 2009; UN-HABITAT, 2011). However, scientific investigation on river flood disasters is very limited in Myanmar, with only limited studies related to soil loss modeling and morphometric analysis (Hlaing et al., 2008) and climate change scenario analysis (Htut et al., 2014) in the Bago River Basin.

In order to address this issue, we developed hydrologic and hydrodynamic models and generated flood inundation maps focusing on the Bago River Basin. Although the design of our study is not new, it is one of very few to have analyzed the flood inundation area in Myanmar. Furthermore, our study is significant because a local climate and hydrological dataset, as well as a topographic dataset, were used to assess the possible flood inundation in the data-scarce country of Myanmar.

Numerical flood simulation models are a useful tool for quantitatively evaluating flooding, which enables researchers to qualitatively evaluate hazard and health risk caused by flooding; however, the approach has disadvantages relating to insufficient datasets in developing countries (Hashimoto et al., 2014). In developing proper assessments and flood control measures to prepare for the next flood disaster, it is important to develop a solid understanding of the actual situation surrounding this flood, including the root causes of flood damage (Komori et al., 2012).

\section{GENERAL DESCRIPTION OF THE STUDY AREA}

The Bago River Basin is a flood prone area in Myanmar. During 2011, two severe floods occurred in the Bago River Basin in July and August. Nearly all of the rivers and creeks were flooded and an adjacent paddy field area of $498 \mathrm{~km}^{2}$ was inundated. Thousands of households and properties were also affected with the duration of inundation above five days for each event.

The Bago River originates from a central mountainous region named Bago Yoma and the largest portion of the river itself is within the Bago Region. A small portion of the river outlet is in Yangon Region where the Bago River joins the Yangon River and, from there, enters the Gulf of Mottama. The basin has a catchment area of $5,348 \mathrm{~km}^{2}$, and the main river is about $331 \mathrm{~km}$ long. Annual total rainfall at Bago station is about 3,300 mm. Only two rain-gauge and water level stations, Bago and Zaung Tu, are located in the Bago River Basin. The location of the Bago River Basin is shown in Figure 1.

In the Bago River Basin, Zaung Tu dam for electricity and a diversion weir for irrigation use were constructed in 1996 and 1998, respectively. A levee running from Bago city to Tarwa was constructed at the left bank due to topographic conditions. For the purpose of flood control, three earthen dams, namely Kodukwe, Salu and Shwelaung, were constructed and completed in 2012. A flood diversion channel from Zaung Tu weir to Moeyongyi lake was also completed in 2012.

\section{METHODOLOGY}

In this study, Hydrologic Engineering System and River Analysis System developed by Hydrologic Engineering Center, US Army Corps of Engineers (HEC-HMS and HECRAS) were utilized as the hydrologic and hydrodynamic models using HEC-GeoHMS and HEC-GeoRAS for linking to a GIS environment. HEC-HMS is widely applied in many water resource studies with reliable outputs (He and Croley, 2007; García et al., 2008; Chen et al., 2009; Olang and Fürst, 2011; Alaghmand et al., 2010, 2012; Joo et al., 2014; Kawasaki et al., 2013). Data were collected from various sources, mainly from the Myanmar government (Table I).

The procedure for developing the flood inundation maps consisted of four steps: (i) extraction of geospatial data, (ii) development of design flood hydrographs, (iii) computation 

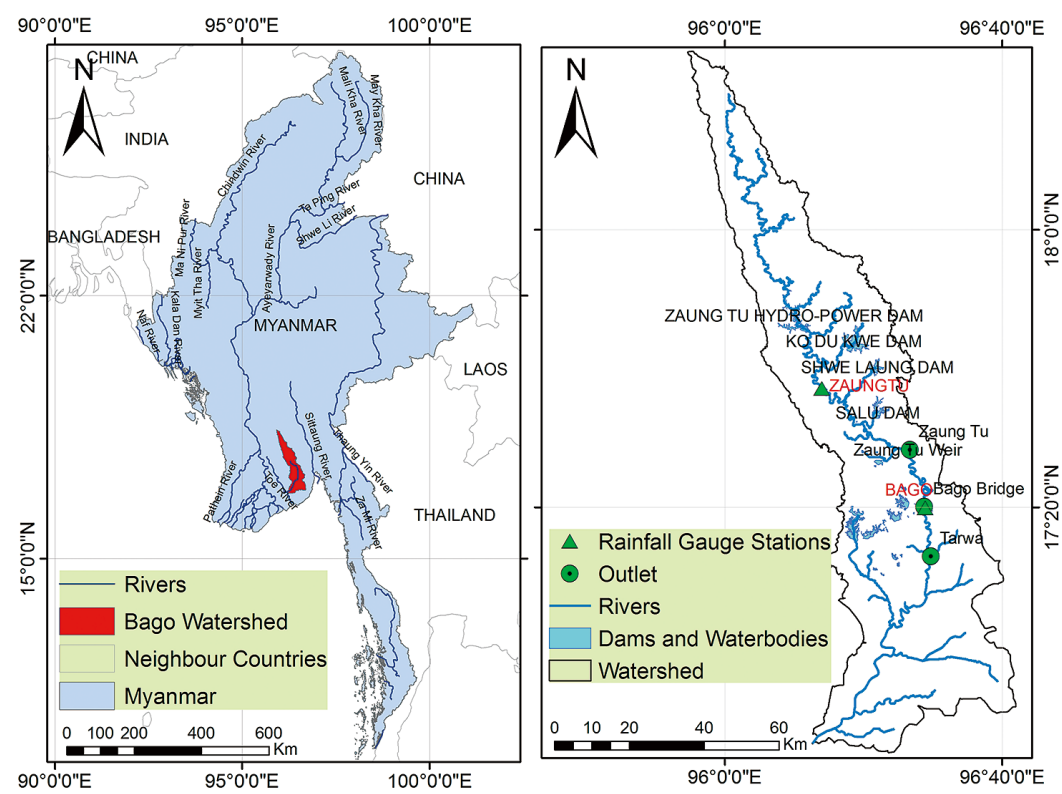

Figure 1. Location of the Bago River Basin, Myanmar

Table I. Data source

\begin{tabular}{ll}
\hline \multicolumn{1}{c}{ Used dataset } & \multicolumn{1}{c}{ Sources } \\
\hline $\begin{array}{l}\text { Daily precipitation [1967-2013] } \\
\text { Daily water level [1987-2013] }\end{array}$ & Department of Meteorology and Hydrology \\
Rating curve for Bago and Zaung Tu & \\
Daily reservoir outflow [2011-2014] & Department of Hydropower \\
Channel surveyed elevation data and map [2013] & Directorate of Water Resources and Improvement of River Systems \\
48 river cross sections [2014] & Irrigation Department \\
Edited 10m- Digital Elevation Model & Khaing (2014) \\
Land cover map [2009] & The European Space Agency GlobCover \\
Soil map [2003] & FAO-UNESCO The Digitized Soil Map of the World \\
PALSAR image of Advanced Land Observing Satellite & Japan Aerospace Exploration Agency (JAXA) \\
(ALOS) [2006] & \\
\hline
\end{tabular}

of water surface profiles and (iv) floodplain mapping and visualization. The overall methodology is shown in Figure 2.

The flood events were applied to the HEC-HMS model using calibration and validation approaches. The design flow hydrographs were generated by HEC-HMS. Water surface profiles were generated by HEC-RAS. The flood inundation map was generated for the $50 \mathrm{~km}$ reach of the Bago River. Two statistical criteria were used to evaluate the calibrated model performance, namely Pearson's coefficient of determination $\left(\mathrm{R}^{2}\right)$ and Nash and Sutcliffe model efficiency (NSE). Flood inundation maps were developed for different return periods $-2,10,50$ and 100 year as future scenarios.

\section{Hydrological modeling}

Hydrological modeling in this study was conducted up to the Tarwa outlet across a catchment study area of $2,800 \mathrm{~km}^{2}$. HEC-HMS was used for hydrological modeling. Soil Conservation Service (SCS) curve number and SCS unit hydrographs were selected for the loss and transform methods, respectively. Recession and lag methods were assigned for the base-flow and routing methods, respectively. Flood inundation mainly occurred in the lower part of the Bago River Basin. The lack of rainfall data in upper part of the Bago River Basin did not seriously affect flood estimation of Bago station. Zaung Tu and Bago rain gauge stations are located in middle part of the Bago River Basin. Rainfall data for the middle part of the Bago River Basin dominated the Bago flood estimation; more rain gauge stations will lead to better results in terms of model calibration.

The time of concentration was 57 hours, with the model parameter set optimized using individual events. Six flood events between 2004 and 2008 were selected for the calibration process. In the calibration procedure, six parameters were adjusted, including initial abstraction, curve number, base-flow initial flow rate, recession constant, base-flow threshold ratio and SCS lag. Six different events were cali- 


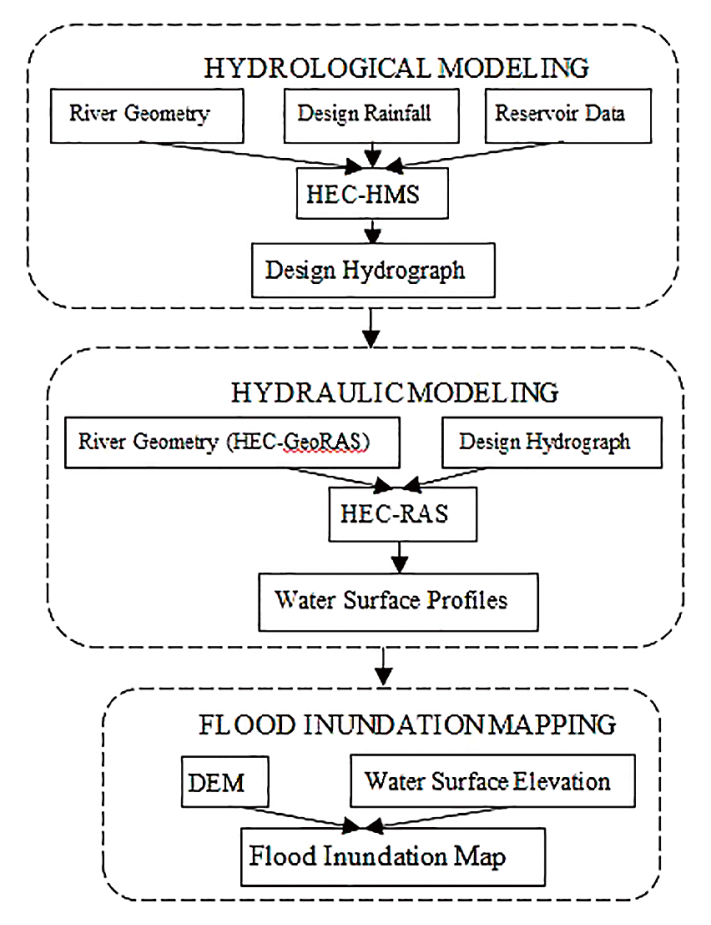

Figure 2. Overall methodology

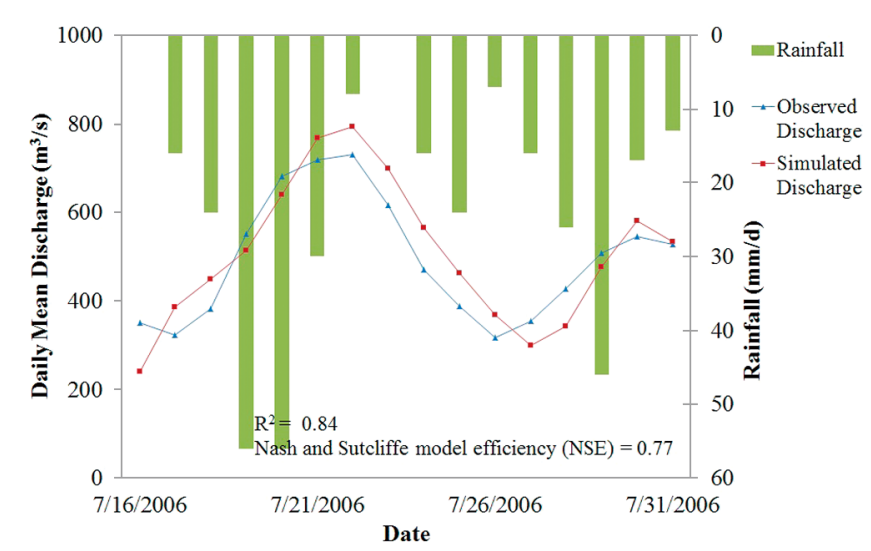

Figure 3. Observed and simulated hydrographs after the calibration process for the 2006 flood event at Bago station

brated by the optimization trial option using the peak weighted root mean square error objective function. The model performance of two flood events in 2007 and 2008 were outside the acceptable range (Model efficiency was less than 0.6). Therefore, optimized model parameter sets from four flood events were averaged to estimate single optimal model parameters. The calibration result for the 2006 flood event is shown in Figure 3. There was a close relationship between the observed and simulated flow, as indicated by an $\mathrm{R}^{2}$ of 0.84 .

Three flood events between 2009 and 2011 were used for validation. Validation results are shown in Table II. $\mathrm{R}^{2}$ and NSE values were 0.9 and 0.78 , respectively, for 2010 flood event. These indicate a close and good correlation between the observed and simulated flow. The validation result of 2010 flood event is shown in Figure 4. Design storms with different return periods were estimated from an
Table II. Validation results of discharge at Bago station

\begin{tabular}{cccc}
\hline Flood events & 2009 & 2010 & 2011 \\
\hline NSE & 0.82 & 0.78 & 0.66 \\
$\mathrm{R}^{2}$ & 0.52 & 0.91 & 0.73 \\
\hline
\end{tabular}

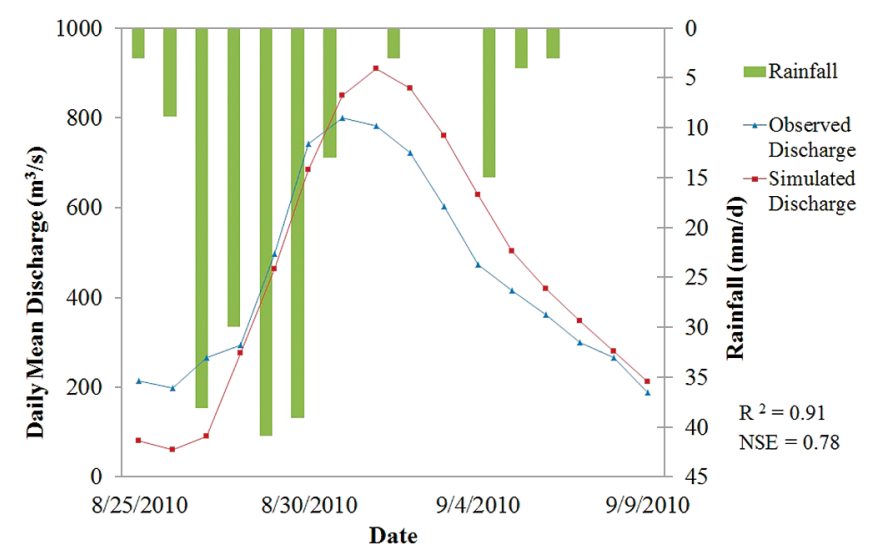

Figure 4. Observed and simulated hydrographs in the validation process for the 2010 flood event at Bago station

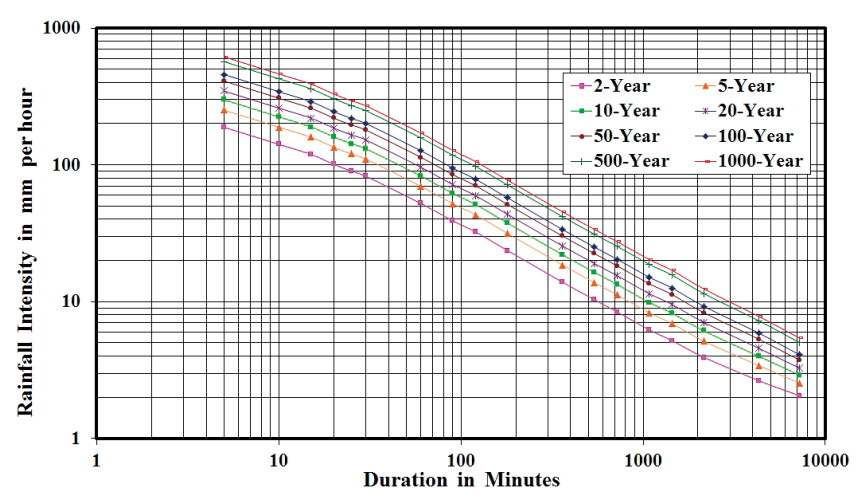

Figure 5. Intensity-duration-frequency curve

intensity-duration-frequency curve shown in Figure 5. Then design floods with different return periods were generated in HEC-HMS.

\section{Hydraulic modeling}

HEC-RAS was used for hydraulic modeling using a river cross-section dataset, Manning's $\mathrm{n}$ values, and flow data including flow rates, flow change locations, and boundary conditions. The 1D HEC-RAS model can be adequately calibrated using hydrometric data, and can then be used to make adequate predictions of flood extent when water free surfaces are extrapolated onto a high resolution DEM (Horritt and Bates, 2002). Hydraulic modeling in this study was conducted for a $50 \mathrm{~km}$ reach starting from Zaung Tu weir to Tarwa outlet using the 48 cross-sections measurement dataset (500 $\mathrm{m}$ to $1,500 \mathrm{~m}$ interval). Boundary conditions at the Zaung Tu Weir, the upstream end of the river system, were assigned to define flow hydrograph. The Bago station was assigned to define uniform lateral inflow hydrograph. The Tarwa station, at the downstream end of the river system, was assigned to define the normal depth and assume the fric- 


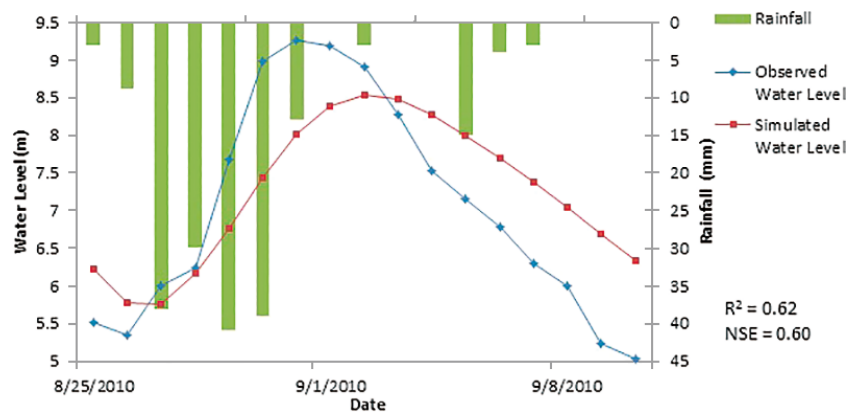

Figure 6. Validation result for the 2010 flood event at Bago station

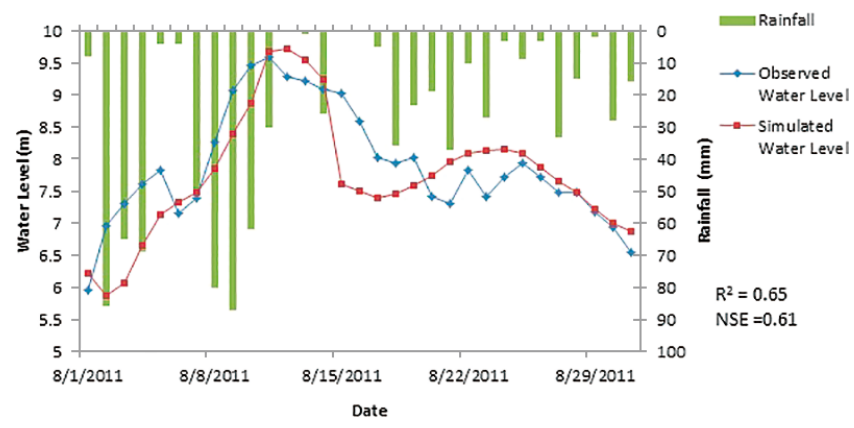

Figure 7. Validation result for the 2011 flood event at Bago station

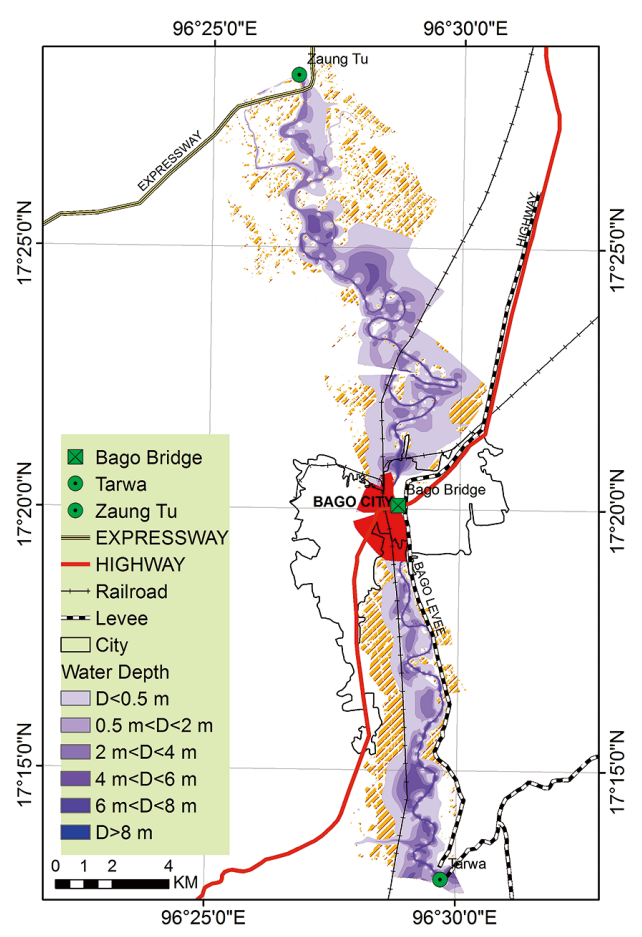

Figure 8. Comparison of the 2006 flood inundation map with an ALOS PALSAR image

Table III. Comparison of predicted flood inundation area for 2006 July flood event

\begin{tabular}{lcccc}
\hline & $\begin{array}{c}\text { Simulated } \\
\text { by the model }\end{array}$ & $\begin{array}{c}\text { Observed by the } \\
\text { ALOS image }\end{array}$ & Over-lapped area & $\begin{array}{c}\text { Over-estimated } \\
\text { by simulation }\end{array}$ \\
\hline Flood area $\left(\mathrm{km}^{2}\right)$ & 51.0 & 42.9 & 41.0 & 4.0 \\
Percentage $(\%)$ & 119.0 & 100.0 & 95.6 & 9.3 \\
\hline
\end{tabular}

tion slope of downstream.

The simulated flow data with time series of flood event were used for calibrating the model. Normal depths were defined as a boundary condition. The unsteady flow condition was adopted to run this model and a friction slope of 0.0003 was applied. The calibration process was undertaken for 3 different flood events between 2004 and 2006. The model was validated with the two different flood events of 2010 and 2011. Validation results for 2010 flood event and 2011 flood event are shown in Figures 6 and 7, respectively. The validation result of 2011 was better than the 2010 result. Satisfactory performance was indicated by the NSE value (0.6).

\section{RESULTS AND DISCUSSION}

The simulated flood inundation maps for the 2006 flood event were validated by comparing the actual flood area derived by ALOS PALSAR images taken on 22nd July during the flood event and that derived using the model (Figure 8). Comparison of the predicted flood inundation area for the July 2006 flood event is shown in Table III.
Flooding around the center of Bago City was over-estimated by the model. However, there is a possibility that the ALOS PALSAR images couldn't detect the flood in the city center appropriately because local authorities and residents reported serious flood damages in the city center. Validation of results for the 2011 flood event was undertaken by comparing the model output with field data. Simulated flood inundation depth and area for 2011 flood event are shown in Figure 9. The inundation urban area simulated by the model and observed flooded urban area for the 2011 flood event are $5.2 \mathrm{~km}^{2}$ and $4.9 \mathrm{~km}^{2}$, respectively (a difference of $6.1 \%$ ).

The degree of flood hazard was classified according to $D$ $<0.5 \mathrm{~m}, 0.5 \mathrm{~m}<D<2 \mathrm{~m}, 2 \mathrm{~m}<D<4 \mathrm{~m}, 4 \mathrm{~m}<D<6 \mathrm{~m}$, $6 \mathrm{~m}<D<8 \mathrm{~m}$, and $D>8 \mathrm{~m}$. The inundation area with classified hazard depths according to 2-, 10-, 50-, and 100-year return periods are shown in Table IV. An increase in the rainfall event return period between 10 -year to 100 -year events caused a $13 \%$ increase in the river flood inundated area. Figure 10 illustrates the generated river flood extent and water depth distribution maps for the 100-year return period.

Considering the 50- and 100-year return period flood scenarios, the highest depth of inundation may affect the Bago City urban areas and around Bago Bridge. The largest flood 


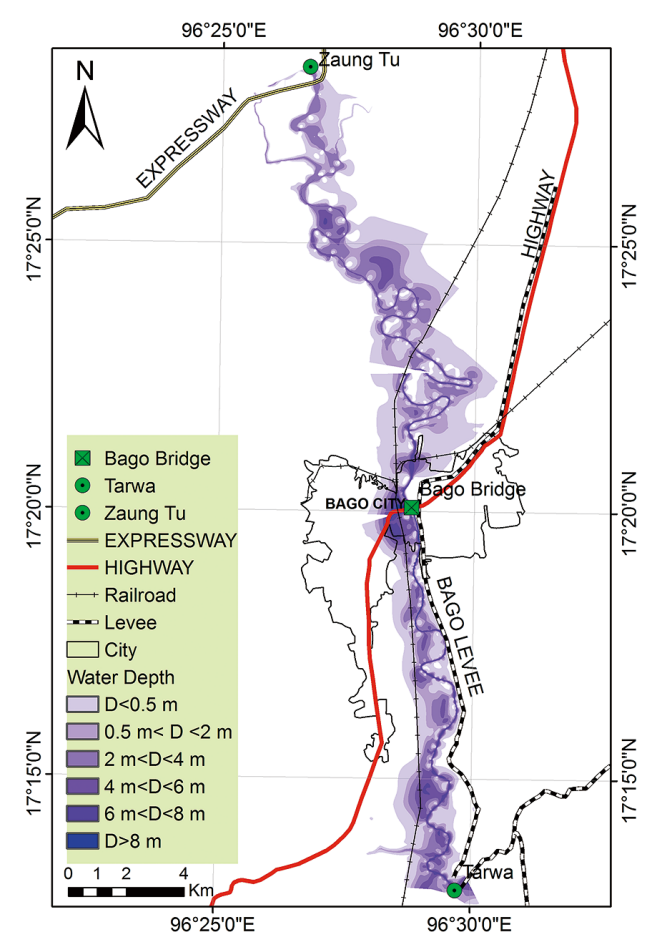

Figure 9. Simulated flood inundation depth and area for the 2011 flood event

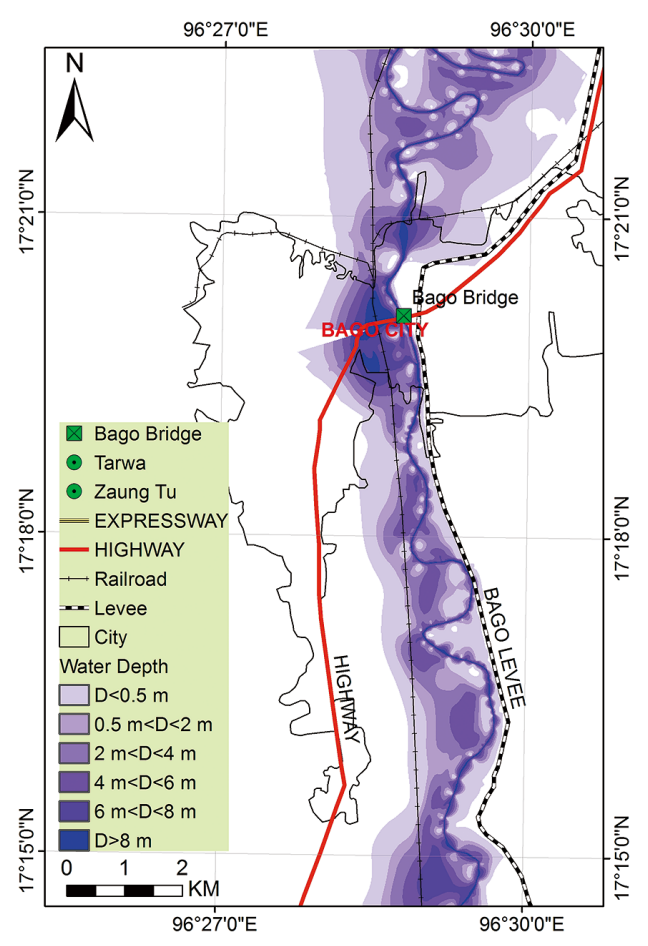

Figure 10. Flood inundation area for a 100-year return period event

Table IV. Flood inundation area with classified water depths in various return periods (Zaung Tu weir to Tarwa outlet reach)

\begin{tabular}{ccccccccc}
\hline & \multicolumn{7}{c}{ Total inundation areas } \\
\cline { 2 - 9 } Water depth $(\mathrm{m})$ & \multicolumn{2}{c}{2 year flood } & \multicolumn{1}{c}{10 year flood } & \multicolumn{2}{c}{50 year flood } & \multicolumn{1}{c}{100 year flood } \\
\cline { 2 - 10 } & Area $\left(\mathrm{km}^{2}\right)$ & $\%$ & Area $\left(\mathrm{km}^{2}\right)$ & $\%$ & Area $\left(\mathrm{km}^{2}\right)$ & $\%$ & Area $\left(\mathrm{km}^{2}\right)$ & $\%$ \\
\hline$D<0.5 \mathrm{~m}$ & 26.45 & 49.58 & 25.65 & 45.09 & 24.9 & 39.27 & 24.7 & 38.53 \\
\hline $0.5 \mathrm{~m}<D<2 \mathrm{~m}$ & 10.64 & 19.94 & 10.93 & 19.22 & 10.77 & 16.99 & 10.72 & 16.72 \\
\hline $2 \mathrm{~m}<D<4 \mathrm{~m}$ & 11.26 & 21.11 & 12.4 & 21.80 & 14.06 & 22.18 & 14.17 & 22.10 \\
\hline $4 \mathrm{~m}<D<6 \mathrm{~m}$ & 3.85 & 7.22 & 5.70 & 10.02 & 9.70 & 15.30 & 10.19 & 15.89 \\
\hline $6 \mathrm{~m}<D<8 \mathrm{~m}$ & 1.10 & 2.06 & 20 & 3.52 & 3.16 & 4.98 & 3.41 & 5.32 \\
\hline$D>8 \mathrm{~m}$ & 0.05 & 0.09 & 0.20 & 0.35 & 0.81 & 1.28 & 0.92 & 1.44 \\
\hline Total & 53.35 & 100.00 & 56.88 & 100.00 & 63.40 & 100.00 & 64.11 & 100.00 \\
\hline
\end{tabular}

extent can reach the rural areas located near the upper areas of Bago City. These large floods can also affect the downstream rural areas including the paddy fields.

\section{CONCLUSIONS}

Flood inundation maps of the Bago River Basin were developed and the result validated by comparing with ALOS PALSAR images from the 2006 flood event. The analysis undertaken demonstrated that the model is currently at the limit of predictive ability for flood inundation, but the results of calibration and validation indicated acceptable results in terms of simulating flood events. The results of the hydrologic model could be further improved by installing a dense network of gauged stations. For a given topography and flow condition, all elements of geometric description including the number of cross-sections, spacing, location and structural details (bridge/culverts) play a key role in describing the inundation extent. For more accurate hydraulic model result, more cross-sections with closer intervals need to be measured. Further study and analysis could consider new dams, which were constructed in 2012 in the Bago River Basin.

From a disaster reduction viewpoint, we believe the information derived from this study can contribute to assessments of potential flood damage for the local region, as well as other locations where data is limited, such as is generally the case in Myanmar. Such an analysis would also be helpful in formulating and directing post-event relief efforts. 


\section{ACKNOWLEDGEMENTS}

This research was supported by Japan Science and Technology Agency (JST)/Japan International Cooperation Agency (JICA), Science and Technology Research Partnership for Sustainable Development Program (SATREPS). We appreciate the Department of Meteorology and Hydrology (DMH) and Irrigation Department (ID) for their helpful advice and provision of data. The author would like to express our special thanks to Mr. Tin Maung, Visiting Professor of Yangon Technological University, for his enthusiastic instructions and advices.

\section{REFERENCES}

Alaghmand S, Abdullah RB, Abustan I, Vosoogh B. 2010. GISbased river flood hazard mapping in urban area (A case Study in Kayu Ara River Basin, Malaysia). International Journal of Engineering and Technology 2: 488-500.

Alaghmand S, Abdullah RB, Abustan I, Said MAM, Vosoogh B. 2012. GIS-Based River Basin flood modelling using HECHMS and MIKE11 - Kayu Ara River Basin, Malaysia. Journal of Environmental Hydrology 20: 1-16.

Asian Disaster Preparedness Center (ADPC), Department of Meteorology and Hydrology (DMH) in Myanmar. 2008. Joint rapid situation assessment report: Status and context of four coastal townships of Yangon and Ayeyarwady Divisions in Myanmar. Bangkok, Thailand; 21.

Chen Y, Xu Y, Yin Y, 2009. Impacts of land use change scenarios on storm-runoff generation in Xitiaoxi Basin, China. Quaternary International 208: 121-128. DOI: 10.1016/j.quaint.2008.12. 014.

Fritz HM, Blount CD, Thwin S, Thu MK, Chan N. 2009. Cyclone Nargis storm surge in Myanmar. Nature Geoscience 2: 448449. DOI: $10.1038 /$ ngeo558.

García A, Sainz A, Revilla JA, Álvarez C, Juanes JA, Puente A. 2008. Surface water resources assessment in scarcely gauged basins in the north of Spain. Journal of Hydrology 356: 312326. DOI: 10.1016/j.jhydrol.2008.04.019.

Hashimoto M, Suetsugi T, Ichikawa Y, Sunada K, Nishida K, Kondo N, Ishidaira H. 2014. Assessing the relationship between inundation and diarrhoeal causes by flood simula- tions in low-income communities of Dhaka city, Bangladesh. Hydrological Research Letters 8: 96-102. DOI: 10.3178/ hrl.8.96.

He C, Croley TE. 2007. Application of a distributed large basin runoff model in the Great Lakes Basin. Control Engineering Practice 15: 1001-1011. DOI: 10.1016/j.conengprac.2007.01. 011.

Hlaing KY, Haruyama S, Aye MM. 2008. Using GIS-based distributed soil loss modeling and morphometric analysis to prioritize watershed for soil conservation in Bago River Basin of lower Myanmar. Frontiers of Earth Science in China 2: 465478. DOI: 10.1007/s11707-008-0048-3.

Horritt MS, Bates PD. 2002. Evaluation of 1D and 2D numerical models for predicting river flood inundation. Journal of Hydrology 268: 87-99. DOI: 10.1016/S0022-1694(02)00121-X.

Htut AY, Shrestha S, Nitivattananon V, Kawasaki A. 2014. Forecasting climate change scenarios in the Bago River Basin, Myanmar. Journal of Earth Science \& Climate Change 5: 228. DOI: $10.4172 / 2157-7617.1000228$.

Joo J, Kjeldsen T, Kim HJ, Lee H. 2014. A comparison of two event-based flood models (ReFH-rainfall runoff model and HEC-HMS) at two Korean catchments, Bukil and Jeungpyeong. KSCE Journal of Civil Engineering 18: 330 343. DOI: $10.1007 / \mathrm{s} 12205-013-0348-3$.

Kawasaki A, Takamatsu M, He J, Rogers P, Herath S. 2013. Developing a forecasting tool of land use for local water resources policy: Case of water demand forecast in the $3 \mathrm{~S}$ sub-basins of the Mekong. Theory and Applications of GIS 21: $65-76$.

Khaing AM. 2014. Mapping flood inundation in the Bago River Basin, Myanmar. Master Thesis, Asian Institute of Technology (AIT), Thailand; 79.

Komori D, Nakamura S, Kiguchi M, Nishijima A, Yamazaki D, Suzuki S, Kawasaki A, Oki K, Oki T. 2012. Characteristics of the 2011 Chao Phraya River flood in Central Thailand. Hydrological Research Letters 6: 41-46. DOI: 10.3178/hrl.6. 41.

Olang LO, Fürst J. 2011. Effects of land cover change on flood peak discharges and runoff volumes: Model estimates for the Nyando River Basin, Kenya. Hydrological Processes 25: 80-89. DOI: 10.1002/hyp.7821.

UN-HABITAT. 2011. Manual on cyclone, causes, effects and preparedness. Yangon, Myanmar; 47. 